\title{
Reforming marriage practices in Bangladesh
}

\section{Sajeda Amin}

Population Council

Follow this and additional works at: https://knowledgecommons.popcouncil.org/departments_sbsr-pgy

Part of the Demography, Population, and Ecology Commons, Family, Life Course, and Society Commons, Gender and Sexuality Commons, and the International Public Health Commons How does access to this work benefit you? Let us know!

\section{Recommended Citation}

Amin, Sajeda. 2008. "Reforming marriage practices in Bangladesh," Promoting Healthy, Safe, and Productive Transitions to Adulthood Brief no. 31. New York: Population Council. 


\section{Reforming marriage practices in Bangladesh}

\section{Prepared by Sajeda Amin}

$\mathrm{M}$ arriage customs in Bangladesh vary by region, complicating national-level efforts to eliminate some of the more harmful practices, such as early marriage and dowry demands, that undermine the status of women. Efforts to reform such a complex and multidimensional institution as marriage must consider economic concerns, social traditions, and social activism.

Dowry demands-in addition to exacting an intolerable financial toll on poor households-have in extreme cases led to gruesome crimes, such as murder or assaults on women whose families could not meet escalating dowry costs. Early marriage-often involving girls as young as 10 -has been widely recognized in Bangladesh and elsewhere as a human rights offense. The Bangladesh penal code includes many sanctions against harmful marriage practices: The Child Marriage Restraint Act dates back to 1921; dowry payments were first banned in 1980, and sanctions were further strengthened in 1985. Men who ask for dowry at marriage can face fines and imprisonment. Yet because both age at marriage and dowry are related to competitive processes in the marriage market, the brute force approach of legal bans and sanctions has not proven sufficient to curtail these harmful practices.

The current legal age at marriage in the country is 18 for women and 21 for men, yet age restrictions are difficult to enforce because Bangladesh lacks an official birth registration system that could be used to verify age. According to the 2004 Demographic and Health Survey, 68 percent of women aged 20-24 were married at age 18 or earlier.

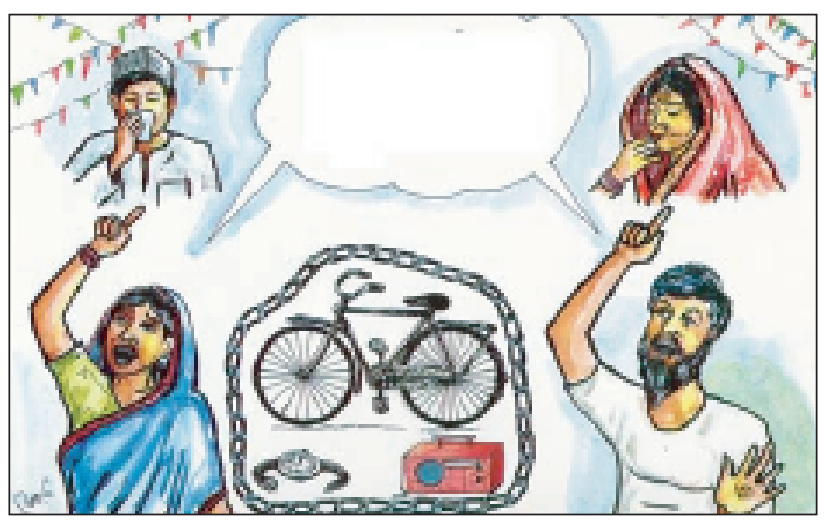

"We shall not take any dowry at our sons' weddings, neither shall we give any dowry at our daughter's wedding. We shall keep our centre free from the curse of dowry. We shall not practice child marriage." http://www.grameen-info.org/bank/the16.html

Although there are no national estimates to quantify the practice of dowry, one study found that 59 percent of marriages that took place between 1980 and 1991 in four northern villages involved dowry (Amin and Cain 1997). This figure compares to the 53 percent reported from a study conducted among women aged 15-49 in Matlab. The same study reported a much lower figure of 13 percent in an urban sample (Naved and Persson 2005). Researchers have traced the rising frequency and cost of dowry in South Asia to a surplus of marriageable women relative to marriageable men-the result of imbalances in age structure combined with large age differences between spouses (Amin and Cain 1997). 
Efforts to discourage dowry and early marriage feature prominently in the social development agendas of many nongovernmental organizations, an approach typified by the microfinance lender Grameen Bank. One of sixteen slogans that all 7.2 million members recite at their weekly meetings states: "We shall not take any dowry at our sons' weddings, neither shall we give any dowry at our daughter's wedding. We shall keep our centre free from the curse of dowry. We shall not practice child marriage."

By studying the circumstances of marriage and its consequences among vulnerable and poor households in rural Bangladesh, the Population Council has developed a nuanced understanding of the relationships between women's status, gender-based violence, early marriage, and the rise of dowry. Highlights from studies on marriage practices undertaken in Bangladesh from 2001 to 2006 , detailed below, yield some insight to potential policy approaches.

\section{New data dispel old assumptions}

Qualitative and quantitative studies conducted in Chapainawabganj, Chittagong, Rajshahi, and Sherpur districts investigated how early marriage and dowry demands interact with poverty, workforce participation, rising education, and variations in local marriage practices. These districts were chosen for their diversity: the communities represented in the survey range from poor to wealthy, highly educated to less-educated, and include areas characterized by high and low rates of early marriage. After analyzing the results of these studies, researchers incorporated questions on marriage practices in a 2005 national survey conducted among 15,492 adolescents. In 2006, a survey in collaboration with the World Bank was conducted among a cohort of younger women (aged 15-25) and older women (aged 35-45) to assess change in marriage practices over time. Researchers are now using the results of these studies to inform programs and policies in an area in which understanding has been largely based on assumptions rather than data.

\section{Understanding dowry and female education patterns}

Previous studies showed that families of better-educated women pay higher dowry amounts than families of lesseducated women; their higher economic status allows them to pay more. In India, dowry has been described as a "groom price," with the higher rates demanded for educated men seen as a reflection of their higher value in the marriage market (Rao 1993). A 2001 survey in three districts of Bangladesh dissected patterns of dowry payments and education into whether a dowry was paid and, if so, what amount. The results revealed an interesting variation on the education-dowry relationship: generally, girls who are educated are considerably more likely to marry without paying dowry. In this regard, education has a positive impact. However, it is also true that when a dowry is paid for an educated woman, the amount paid is substantially higher than the price paid for less-educated women. By contrast, a higher proportion of girls with no education paid dowry, although amounts were generally small. This pattern suggests that the marriage strategies pursued by the parents of educated versus uneducated girls differ considerably, and education offers a wider range of marriage strategies including marriages of the couple's own choosing that typically do not involve a dowry (Huq and Amin, 2001; Suran, Amin, Huq, and Chowdhury 2004).

A qualitative study in the Rajshahi division, where dowry and early marriage are both highly prevalent, explored the relationship between girls' education and dowry demands. A national secondary school scholarship for girls who attend rural schools in Bangladesh has helped reduce the gender gap in schooling. Researchers assessed whether this program, considered a prime example of how conditional cash transfers can positively affect schooling outcomes, has also had an impact on the practice of dowry. While there was no evidence of an effect on dowry, one positive result of the increase in girls' school enrollment was a narrowing of the educational gap between spouses, with implications for greater equality (Huq and Amin 2001).

\section{Dowry and gender-based violence}

A second issue explored in a set of papers is the association between spousal abuse and dowry payments using data from a panel study that included recently married girls. Abuse was found to be lowest among girls whose families did not pay dowry. Among girls whose families paid dowry, abuse was highest in the lowest dowry quintile and decreased with increasing dowry payments. Dowry payments were also inversely related with other measures of wellbeing. Women who did not pay dowry reported more time spent in self-care and other small indulgences that constitute 
leisure than did women who paid dowry. These results suggest that for women who are not well-endowed-physically, economically, or socially_dowry demands may be a result of the bride's weak bargaining position. The qualitative data strongly suggest that beauty, health, sexual purity, family status, and good social networks help facilitate a good match in the marriage market (Suran, Amin, Huq, and Chowdhury 2004; Amin and Suran 2005a). These factors are difficult to measure in surveys and remain part of the unexplained variation in the quantitative analysis of dowry.

\section{Regional variation in dowry payments}

While the rise in dowry demands is generally recognized as cause for alarm, the only data on dowry patterns come from small-scale studies. In 2005, a national adolescent survey conducted by the Council and BRAC, a Bangladeshi nongovernmental organization, was the first to show national patterns and yield a national estimate. The study revealed a surprising pattern of variation in early marriage and dowry payments across the country's 64 districts. The proportion of marriages involving dowry ranged from 20 to 80 percent among married women under age 25 . At the district and regional level, later marriage was associated with greater prosperity but higher dowry payments. Although the large variation in marriage patterns in a country that is otherwise homogeneous is difficult to explain, there are some common patterns. For instance, the lowest proportions reporting dowry are in Barisal and Sylhet, two districts that are experiencing increasing religious conservatism and a high rate of migration. Barisal has a long tradition of migration to the capital city, Dhaka, initially of men and in more recent years of women, while Sylhet has been an important source of Bengali migrants to the United Kingdom.

\section{Poverty and dowry}

The rising prominence of dowry adds an additional dimension of vulnerability among the poor. While a higher proportion of the poor pay dowry, they pay small amounts, with generally detrimental implications for the girls given in marriage. According to a 2005 qualitative study conducted by the Population Council, girls from poor families have fewer suitors and are more likely to agree to hasty proposals that result in mismatches and bad marriages. Abuse, polygamy, divorce, and widowhood are common among poor married girls, especially those from female-headed households.
Unanticipated economic shocks such as a crop failure or the incapacitation of a working family member are particularly strongly associated with untimely and hasty marriages and poor outcomes in later life (Amin, Selim, and Waiz 2006).

\section{Trends in marriage and the correlates of} marriage practices

An analysis of 2006 World Bank survey data confirmed the pattern of variation revealed in the adolescent data. A comparison of younger and older women revealed that the practice of dowry payment, which now varies considerably by region, was universally low in the past. On the other hand, regions that currently have late marriage patterns had relatively late marriages in the past as well. Because this survey included questions about gender norms more generally, the investigators were able to explore the associations between marriage characteristics and indicators of women's well-being after marriage. They found that while dowry is associated with negative outcomes for women following marriage, early marriage did not show the same pattern of negative associations per se. The analysis also found that education has a strong association with a range of positive empowerment indicators. The impact of poverty is strongly associated with relative economic status between natal and marital families. The poor generally had lower indicators of empowerment.

\section{Future directions for research and policy}

The considerable variability in marriage practices throughout Bangladesh raises questions about an appropriate national marriage strategy. Clearly, local factors lead to these variations. Migration may be an important social force at work. Islamic activism and the actions of nongovernmental organizations such as Grameen may also contribute to this variability. The influence of Grameen and similar organizations may work in multiple ways: on the one hand creating a strong ideational message against dowry as illustrated above; on the other hand providing the necessary cash (through micro-enterprise loans) to fuel rising dowry costs. One way to tease out some of these patterns is through panel studies that provide detailed data on natal and marital families.

An ideational approach to future programs may be to promote the income streams of wage-earning women as a substitute for dowry. For example, studies among female 
garment workers suggest that their potential contributions to household income as wage-earners could be seen as an adequate substitute for dowry. Future studies could contrast working and nonworking women to see how earning an income changes the valuation of women within the household and whether such changes have implications for marriage timing and transactions.

Studies should also use data from the 2005 national survey to explore differences among communities that differ in their marriage practices. The implications of these variations for women's well-being can then be investigated to suggest future directions in policy to bring about more positive marriage practices. These studies should also be used to explore longer-term consequences of early marriage and dowry payments.

Researchers should pay more attention to female labor migration and its effects on marriage. Ideally, such longitudinal studies would track migrants to their destinations. Longitudinal study designs can also be beneficial in tracking the impact of new programs such as birth registration schemes.

These studies should be designed to identify the influences operating at the individual, household, and community levels with regard to the economic dimensions of marriage change. In particular, questions on aspirations and expectations regarding future income streams have implications for dowry expectations among young girls.

\section{References and related publications}

Amin, Sajeda 2007. "Variations in marriage over time and space in Bangladesh," Background paper commissioned by the World Bank for the Bangladesh Country Gender Assessment.

Amin, Sajeda and Mead Cain. 1997. "The rise of dowry in Bangladesh," in Gavin W. Jones, John C. Caldwell, Robert M. Douglas, and Rennie M. D'Souza (eds.), The Continuing Demographic Transition. Oxford: Oxford University Press.

Amin, Sajeda, Simeen Mahmud, and Lopita Huq. 2002. "Rural adolescents in Bangladesh, 2002: A report drawn from the baseline survey for the Bangladesh adolescent girls' livelihood Kishori Abhijan project." Dhaka, Bangladesh: UNICEF.

Amin, Sajeda, Nasheeba Selim, and Nashid Kamal Waiz. 2006. "Causes and consequences of early marriage in Bangladesh," background report for workshop on programs and policies to prevent early marriage. Dhaka: Population Council.

Amin, Sajeda and Luciana Suran 2005a. "The impact of marriage payments on leisure, housework, and abuse of young wives: Some evidence from rural Bangladesh," paper presented at the Annual Meeting of the Population Association of America, Philadelphia.

Amin, Sajeda and Luciana Suran. 2005b. "Program efforts to delay marriage through improved opportunities: Some evidence from rural Bangladesh," paper presented at the Annual Meetings of the International Union for the Scientific Study of Population, Tours, France and the Population Association of America, Philadelphia.

Gardner, Katie. 1995. Global Migrants, Local Lives-Travel and Transformation in Bangladesh. Oxford: Clarendon Press.

Huq, Lopita and Sajeda Amin. 2001. "Dowry negotiations and the process of union formation in rural Bangladesh: The implications of rising education," paper presented at the Annual Meeting of the Population Association of America, Washington, DC.

Naved, Ruchira T. and Lars A. Persson 2005. "Factors associated with spousal physical violence against women in Bangladesh," Studies in Family Planning 36(4): 289-300.

Rao, Vijayandra. 1993. "Dowry 'inflation' in rural India: A statistical investigation," Population Studies 47(2):283-293.

Suran, Luciana, Sajeda Amin, Lopita Huq, and Kobita Chowdhury. 2004. "Does dowry improve life for brides? A test of the bequest theory of dowry," Policy Research Division Working Paper no. 195. New York: Population Council.

\section{Donors}

Department for International Development (DFID), Hewlett Foundation, Mellon Foundation, Rockefeller Foundation, UNICEF, USAID, Gates Foundation, European Donor Consortium, Nike Foundation, World Bank

\section{For more information or for copies of other Briefs, contact publications@popcouncil.org For additional resources see www.popcouncil.org/pgy}

Population Council

One Dag Hammarskjold Plaza

New York, New York 10017 USA

(C) 2008 by The Population Council, Inc. 